\title{
Optimizing the biosynthesis of renewable polyhydroxyalkanoate copolymer containing 3-hydroxyvalerate by Massilia haematophila using statistical modeling
}

\author{
Jong T. Kiun ${ }^{1}$, Tan S. M. Amelia ${ }^{1}$, Kai Hee Huong ${ }^{2}$, \\ Al-Ashraf Abdullah Amirul ${ }^{2,3}$, KeSAVEn Bhubalan ${ }^{1,3}$ * \\ ${ }^{1}$ Faculty of Science and Marine Environment, Universiti Malaysia Terengganu, Kuala Nerus, Terengganu, Malaysia \\ ${ }^{2}$ School of Biological Sciences, Universiti Sains Malaysia, Penang, Malaysia \\ ${ }^{3}$ Malaysian Institute of Pharmaceuticals and Nutraceuticals (Ipharm), NIBM, Penang, Malaysia
}

\begin{abstract}
Polyhydroxyalkanoate (PHA) is a microbial storage polymer that is naturally produced by certain bacteria. This is the first study on the ability of this particular species Massilia haematophila to synthesize a PHA copolymer containing 3-hydroxyvalerate (3HV) monomer. Using the statistical design on Massilia haematophila UMTKB-2, this study highlights the optimization of poly(3-hydroxybutyrate-co-3-hydroxyvalerate), $\mathrm{P}(3 \mathrm{HB}-\mathrm{co}-3 \mathrm{HV})$, copolymer production for shaken-flask cultivation. Moreover, the mechanical and thermal features of the polymers were determined. The production of $\mathrm{P}(3 \mathrm{HB}-\mathrm{co}-3 \mathrm{HV})$ by Massilia haematophila UMTKB-2 using optimal conditions provided by response surface methodology (RSM) yielded $5.0 \mathrm{~g} / \mathrm{l}$ of $\mathrm{P}(3 \mathrm{HB}-\mathrm{co}-7 \mathrm{~mol} \% 3 \mathrm{HV})$, which was higher than the value obtained from unoptimized conditions such as $4.40 \mathrm{~g} / \mathrm{l}$ of $\mathrm{P}(3 \mathrm{HB}-\mathrm{co}-4 \mathrm{~mol} \% 3 \mathrm{HV})$. This result showed a $14 \%$ increase in copolymer concentration and a two-fold increase in $3 \mathrm{HV}$ composition. In this study, the $\mathrm{P}(3 \mathrm{HB}-\mathrm{co}-3 \mathrm{HV})$ synthesized was determined as a block copolymer and its thermal properties were better than $\mathrm{P}(3 \mathrm{HB})$. Using RSM, the optimization conditions were successfully obtained for this bacterium, and this result is a starting platform for additional studies of a larger scaled PHA production from Massilia haematophila UMTKB-2 using bioreactors.
\end{abstract}

Key words: 3-hydroxyvalerate, biorenewable, Massilia haematophila, optimization, polyhydroxyalkanoate, response surface methodology

\section{Introduction}

Nowadays, the increasing demand of petrochemicalbased plastic is essentially because of its outstanding chemical and physical features such as resistance towards chemical and thermal degradation, which allows it to endure in an exposed environment (Loo and Sudesh, 2007). However, using a petrochemical-based plastic is environmentally unfriendly because of its non-biodegradable properties and requirement of a constant supply of finite resources. The amount of plastic dis- posed into the marine environment has annually been estimated to reach 12.7 million metric tons from landbased sources (Jambeck et al., 2015).

Environmental awareness has led people to gradually replace petrochemical-based plastic with biodegradable plastic to mitigate environmental issues. There are multiple types of biodegradable polymers such as polylactide (PLA), starch-based polymers, and polyhydroxyalkanoate (PHA). These polymer types are completely degradable in the environment within a short time pe-

* Corresponding author: Faculty of Science and Marine Environment, Universiti Malaysia Terengganu, Kuala Nerus, 21030 Terengganu,
Malaysia; Malaysian Institute of Pharmaceuticals and Nutraceuticals (Ipharm), NIBM, 11700, Penang, Malaysia; e-mail: kesaven@umt.edu.my 
riod; thus, they are more environmentally friendly than the petrochemical-based plastic. The PHA polymer is one of the most popular groups of biodegradable polymers that has been extensively studied and commercialized (Kourmentza et al., 2017). According to a recent study, the global market for PHA increased by US $\$ 19.63$ million from an estimated US $\$ 72.63$ million in 2016 to US\$92.25 million by 2021 (Kourmentza et al., 2017).

For certain bacterial cytoplasms, PHA is a type of natural biodegradable polymer that is synthesized as intracellular granules (Sudesh et al., 2011). These granules are energy and carbon reserves in situations with an excessive carbon source and limited nutrients (Lee et al., 1999). Recently, there have been $\sim 150$ different PHA structures in which homopolymers and copolymers have been identified (Kourmentza et al., 2017). Moreover, PHA has been classified into two groups according to the size of monomers: medium-chain-length PHA (MCL PHA) and short-chain-length PHA (SCL PHA). In the monomer units, the MCL PHA comprises six to fourteen carbon atoms, whereas the SCL PHA comprises three to five carbon atoms (Narayanan and Ramana, 2012).

Poly(3-hydroxybutyrate), $\mathrm{P}(3 \mathrm{HB})$, is the most commonly produced PHA homopolymer. Nevertheless, its application has been restricted because of its poor mechanical properties. Many researchers have performed studies to enhance the features of $\mathrm{P}(3 \mathrm{HB})$, including thermal and mechanical properties, by incorporating comonomer units such as 3-hydroxyhexanoate (3HHX), 3-hydroxyvalerate (3HV), 3-hydroxyoctanoate (3HO), or 4-hydroxybutyrate (4HB) to form copolymers (Loo and Sudesh, 2007). P(3HB-co-3HV) is a well-known copolymer that has been extensively studied (Zakaria et al., 2010), which can be obtained by feeding a homopolymer with precursors with odd carbon-numbers, namely, heptanoic acid, valeric acid, levulinic acid, propionic acid, and sodium valerate (Koller et al., 2014). The $\mathrm{P}$ (3HB-co$3 \mathrm{HV}$ ) copolymer is relatively less crystalline and more ductile than most copolymers. Hence, it is suitable for applications that require similar properties such as shampoo bottles, cosmetic containers, cardboard and film and personal hygiene articles (Shantini et al., 2013).

The major challenge in PHA commercialization is its production cost, which is dependent on the fermentation processes. For bacterial fermentation, strain productivity is an important factor, which can often be improved by fine-tuning culture parameters using statistical de- signs. Efforts have been taken to statistically optimize the accumulation of various PHA types by selected production strains (Shantini et al., 2012; Yatim et al., 2017). One-factor-at-a-time, which is executed by experimentally observing the effect of one variable at a time, is a traditional technique for improving PHA fermentation. The disadvantages of this approach are that it is laborious and tedious and that one cannot study the interaction of more than two factors (Zafar et al., 2012). Recently, this method has been replaced by a statistical optimization method such as a response surface methodology (RSM), which is the common statistical and mathematical design used for building an experimental design, evaluating the interaction effect between factors, and finding optimum circumstances of variables for suitable responses in various biochemical processes (Morshedi and Akbarian, 2014).

Massilia haematophila (known as Naxibacter haematophila) is a non-motile, non-spore-forming, rod-shaped, Gram-negative, fastidious, and slow-growing bacterium that can be safely handled in Biosafety Level 2 laboratory (Kampfer et al., 2008; Kampfer et al., 2011). There have been reports on identifying other bacteria from the Massilia genus from soil, air, drinking water, terrestrial, and aquatic plants (Bassas-Galia et al., 2012; Cerrone et al., 2012; Han et al., 2014). The ability of genus Massilia to produce PHA was earlier reported but limited to only $\mathrm{P}(3 \mathrm{HB})$, and the conditions for optimising the PHA synthesis and copolymer producibility of this genus have not been studied in detail (Bassas-Galia et al., 2012; Cerrone et al., 2012; Han et al., 2014).

Previously, researchers have reported that a newly isolated Massilia haematophila UMTKB-2 from brackish water was able to incorporate $3 \mathrm{HV}$ comonomer (Kiun et al., 2016). In this study, researchers studied in-depth the $\mathrm{P}(3 \mathrm{HB}-\mathrm{co}-3 \mathrm{HV})$ copolymer production and optimization by $M$. haematophila UMTKB-2. The production of $\mathrm{P}(3 \mathrm{HB}-\mathrm{co}-3 \mathrm{HV})$ copolymer in shaken-flask cultivations was optimized using alcohol- and acid-based $3 \mathrm{HV}$ precursors. Consequently, this is the first study on the Massilia genus producing the PHA copolymer with a 3-hydroxyvalerate monomer. This study's results may help in establishing fermentation conditions for a scaled-up production of $\mathrm{P}(3 \mathrm{HB}-\mathrm{co}-3 \mathrm{HV})$ copolymer by this strain and for investigating its potential for accumulating other types of PHA comonomers. 


\section{Materials and methods}

\section{Bacterial strain}

In this study, M. haematophila UMTKB-2, previously isolated from brackish water, was investigated (Kiun et al., 2016). This strain was retained on nutrient-rich agar (10 g of a beef extract, $2 \mathrm{~g}$ of yeast extract, $10 \mathrm{~g}$ of peptone, and $14 \mathrm{~g}$ of bacteriological agar powder in 11 of distilled water) for $24 \mathrm{~h}$ at $30^{\circ} \mathrm{C}$ and $200 \mathrm{rpm}$. The beef extract, yeast extract, peptone, bacteriological agar powder, glucose, chloroform, and methanol were purchased from Thermo Fisher Scientific (Massachusetts, USA), and $\mathrm{KH}_{2} \mathrm{PO}_{4}, \mathrm{Na}_{2} \mathrm{HPO}_{4}$, urea of analytical reagent (AR) grade, and other chemicals were purchased from Merck (Darmstadt, Germany).

\section{Bacterial growth and the biosynthesis of PHA}

The bacteria were first precultured in $50 \mathrm{ml}$ of nutrient-rich broth in a 250-ml Erlenmeyer flask. Approximately 2 loopfuls of $M$. haematophila UMTKB-2 were inoculated and the culture was incubated in a Certomat orbital shaker by Sartorius (Goettingen, Germany) for $12 \mathrm{~h}$ at $200 \mathrm{rpm}$ at $30^{\circ} \mathrm{C}$. Then, $0.1 \mathrm{~g} / 1$ of pre-cultured cells was transferred into $50 \mathrm{ml}$ of mineral salt medium (MSM) in a 250-ml Erlenmeyer flask. The MSM comprised $0.03 \mathrm{~g} / 1$ of $\mathrm{MgSO}_{4} \cdot 7 \mathrm{H}_{2} \mathrm{O}, 2.8 \mathrm{~g} / \mathrm{l}$ of $\mathrm{KH}_{2} \mathrm{PO}_{4}, 3.32 \mathrm{~g} / \mathrm{l}$ of $\mathrm{Na}_{2} \mathrm{HPO}_{4}$, $0.3 \mathrm{~g} / \mathrm{l}$ of urea, and $1 \mathrm{ml} / 1$ of trace elements solution (1.98 g $\mathrm{MnCl}_{2} \cdot 4 \mathrm{H}_{2} \mathrm{O}, 0.29 \mathrm{~g} \mathrm{ZnSO}_{4} \cdot 7 \mathrm{H}_{2} \mathrm{O}, 2.78 \mathrm{~g}$ $\mathrm{FeSO}_{4} \cdot 7 \mathrm{H}_{2} \mathrm{O}, 1.67 \mathrm{~g} \mathrm{CaCl}_{2} \cdot 2 \mathrm{H}_{2} \mathrm{O}, 0.17 \mathrm{~g} \mathrm{CuCl}_{2} \cdot 2 \mathrm{H}_{2} \mathrm{O}$, and $2.81 \mathrm{~g} \mathrm{CoSO}_{4} \cdot 7 \mathrm{H}_{2} \mathrm{O}$ per litre of $0.1 \mathrm{M} \mathrm{HCl}$ ) (Doi, 1995; Amirul et al., 2008). Sterilized glucose, as a carbon source, and precursors were supplied into the MSM medium using smooth-walled flasks, and then fermented on the orbital shaker for $72 \mathrm{~h}$ at $30^{\circ} \mathrm{C}$ and $200 \mathrm{rpm}$ to promote bacterial growth and PHA production. The cell growth was determined after $72 \mathrm{~h}$, and the culture was pelleted and washed twice with distilled water before measuring the optical density of the culture at $600 \mathrm{~nm}$ using the Genesys 10S UV-vis spectrophotometer (Thermo Fisher Scientific, Massachusetts, USA). Then, the culture was harvested by pelleting with Sartorius Centrifugation Sigma 3-18K (Goettingen, Germany).

\section{Experimental design for optimizing copolymer P(3HB-co-3HV)}

\section{One-factor-at-a-time method (OFAT)}

The OFAT method was performed according to Aghjeh and Aramvash (2015). All experiments were car- ried out using the abovementioned MSM. The influence of the carbon to nitrogen $(\mathrm{C} / \mathrm{N})$ ratio $(10,20,30,40$, and 50 ), $3 \mathrm{HV}$ precursors (1-pentanol, valeric acid, sodium propionate, and sodium valerate), and the incubation time on the production of $\mathrm{P}(3 \mathrm{HB}-c o-3 \mathrm{HV})$ copolymer were investigated. All cultures were incubated on the orbital shaker for $72 \mathrm{~h}$ at $30^{\circ} \mathrm{C}$ and $200 \mathrm{rpm}$. All the experiments were then conducted in triplicates.

\section{Response surface methodology}

The central composite design (CCD) was conducted using the Design Expert software(trial version 9.0) by Stat-Ease (Minneapolis, USA) (Shantini et al., 2012). Three variables were investigated, namely, 1-pentanol concentration, agitation and incubation time. A number of 20 experimental designs were constructed by the Design Expert software. Two responses, PHA concentration and 3HV monomer composition were tested in CCD.

The statistical analysis of the model was completed using the ANOVA procedure. The ANOVA, which included Fisher's F test, a lack of fit test, and the correlation coefficient $R^{2}$, was used to model the adequacy. Three-dimensional (3D) surface plots were constructed to graphically envisage the interactions among variables by maintaining one factor at a constant value while altering the other two independent factors. The experimental result was fitted using a second-order polynomial equation (Morshedi and Akbarian, 2014):

$$
\begin{aligned}
Y & =\alpha_{0}+\alpha_{1} \chi_{1}+\alpha_{2} \chi_{2}+\alpha_{3} \chi_{3}+\alpha_{11} \chi_{1}^{2}+\alpha_{22} \chi_{2}^{2}+\alpha_{33} \chi_{2}^{3}+ \\
& +\alpha_{12} \chi_{1} \chi_{2}+\alpha_{13} \chi_{1} \chi_{3}+\alpha_{23} \chi_{2} \chi_{3}
\end{aligned}
$$

where $Y$ is the predicted response; $\alpha_{0}$ is the offset item; $\alpha_{1}, \alpha_{2}$, and $\alpha_{3}$ are linear coefficients, $\alpha_{11}, \alpha_{22}$, and $\alpha_{32}$ are quadratic coefficients; and $\alpha_{12}, \alpha_{13}$, and $\alpha_{23}$ are interaction coefficients. The Design Expert software was used to design the second-order polynomial coefficients. To verify the validity of the optimal condition predicted by Design Expert software, a biosynthesis was performed using the shaken-flask cultivation approach. The experiment was then carried out in triplicates.

\section{Analytical methods of P(3HB-co-3HV)}

The accumulation of PHA, including the monomer composition and the PHA content in the lyophilized cells, was analyzed using gas chromatography (GC-2014, Shimadzu, Kyoto, Japan) as defined by Braunegg et al. (1978). The lyophilized cells ( 15 to $20 \mathrm{mg}$ ) were used for methanolysis, which comprised $85 \%$ (v/v) methanol and 
$15 \%(\mathrm{v} / \mathrm{v})$ concentrated sulphuric acid. The mixture was heated for $2 \mathrm{~h}$ and $20 \mathrm{~min}$ at $100^{\circ} \mathrm{C}$. A volume of $1 \mathrm{ml}$ distilled water was inserted, vortexed and then left overnight for separation. Subsequently, the organic layer was separated and dried over $\mathrm{Na}_{2} \mathrm{SO}_{4}$. A volume of $500 \mu \mathrm{l}$ caprylic methyl (CME) solution as an internal standard and $500 \mu \mathrm{l}$ of the sample were then transferred into the vial. The sample was analyzed using $30 \mathrm{~m} \times 0.25 \mathrm{~mm} \times$ $0.25 \mu \mathrm{m}$ film thickness of SPB-1 Fused Silica Capillary Column (Supelco, Pennsylvania, USA).

\section{Extraction and preparation of $\mathrm{P}(3 \mathrm{HB}-\mathrm{co}-3 \mathrm{HV})$ polymer film}

The polymer was extracted by dissolving $1 \mathrm{~g}$ of lyophilized cells in $200 \mathrm{ml}$ of chloroform, and then it was stirred at room temperature for $48 \mathrm{~h}$ (Amirul et al., 2008). Next, the mixture was filtered, after which the filtrate was collected in a round bottom flask. Then, the filtrate was concentrated using a R-200 rotary evaporator (BÜCHI, Flawil, Switzerland) and precipitated in cold methanol. The precipitated polymer was subsequently filtered by a $0.45 \mu \mathrm{m}$ PTFE membrane (Sartorius, Goettingen, Germany), and the polymer was placed in a fume hood (Esco, Singapore) at room temperature for drying. Next, a polymer film was developed using a solventcasting technique by dissolving $\sim 0.5 \mathrm{~g} / 1$ of polymer in $25 \mathrm{ml}$ of chloroform. Then, the mixture was transferred in a glass Petri dish of having a diameter of $9 \mathrm{~cm}$ and dried at room temperature.

\section{Characteristics of $\mathrm{P}(3 \mathrm{HB}-\mathrm{co}-3 \mathrm{HV})$}

\section{Nuclear magnetic resonance analysis}

Deuterated chloroform $\left(\mathrm{CDCl}_{3} ; 1 \mathrm{ml}\right)$ was used to dissolve about $25 \mathrm{mg}$ polymer film at a total concentration of $25 \mathrm{mg} / \mathrm{ml}$. The solution was subjected to $700 \mathrm{MHz}$ NMR analysis (Bruker, Massachusetts, USA). Consequently, $\mathrm{Me}_{4} \mathrm{Si}$, which acted as an internal chemical shift reference, was used (Amirul et al., 2008). Then, polymer randomness was determined using ${ }^{13} \mathrm{C}-\mathrm{NMR}$ analysis by referring to the carbonyl resonances. The dyad sequence distributions of the $3 \mathrm{HV}$ and $3 \mathrm{HB}$ units in the copolymers were described by Bernoullian statistics and simplified as shown:

$$
\begin{gathered}
K_{V V}=K_{V}^{2} \\
K_{B V}=K_{B V}=K_{V}\left(1-K_{V}\right) \\
K_{B B}=\left(1-K_{V}\right)^{2}
\end{gathered}
$$

Parameter $D$ was used to analyze the variation degree from a random arrangement of monomer units. This parameter was determined based on the dyad fractions defined by Kamiya et al. (Kamiya et al. 1989) using the following equation:

$$
D=F_{B B} F_{V V} / F_{B V} F_{V B}
$$

\section{Mechanical and thermal properties of $\mathrm{P}(3 \mathrm{HB}-\mathrm{co}-3 \mathrm{HV})$}

A tensile machine Al-3000 with load cell (Gotech Testing Machines, Taichung City, Taiwan) capacity at $100 \mathrm{~N}$ was used to determine the mechanical properties. A dumbbell shape of $75 \mathrm{~mm}$ length and $4 \mathrm{~mm}$ width was cut out of a polymer film using steel punches according to the American Society for Testing and Materials (ASTM) F638-93 standard. The cross-head speed applied was $20 \mathrm{~mm} / \mathrm{min}$ (Huong et al. 2015).

A differential scanning calorimetry (DSC) machine (Perkin Elmer, Massachusetts, USA) was used to analyze the thermal properties (Huong et al., 2017). An aluminium pan was used to enclose $\sim 5-8 \mathrm{mg}$ of polymer film. Then, the sample was heated, quenched, and reheated in a temperature range of -50 to $200^{\circ} \mathrm{C}$. The cooling and heating rate were subsequently $20^{\circ} \mathrm{C} / \mathrm{min}$ and $10^{\circ} \mathrm{C} / \mathrm{min}$, respectively.

\section{Results and discussion}

\section{Variation of $\mathrm{C} / \mathrm{N}$ ratios on $\mathrm{P}(3 \mathrm{HB})$ production}

The production of $\mathrm{P}(3 \mathrm{HB})$ using various $\mathrm{C} / \mathrm{N}$ ratios, with glucose as a carbon source and urea as a nitrogen source, is shown in Table 1. Cerrone et al. (2012) reported that seven species from the Massilia genus, including Massilia albidiflava, Massilia dura, Massilia lutea, Massilia brevitalea, Massilia aurea, and Massilia plicata, could synthesize $\mathrm{P}(3 \mathrm{HB})$ using starch without fixing the $\mathrm{C} / \mathrm{N}$ ratio. Because $M$. haematophila has never been screened for the best $\mathrm{C} / \mathrm{N}$ ratio of $\mathrm{P}(3 \mathrm{HB})$ production, we tested a well-known range based on previous reports. $\mathrm{A} \mathrm{C} / \mathrm{N}$ ratio of 50 yielded the maximum $\mathrm{P}(3 \mathrm{HB})$ production and bacterial growth in this study. The $\mathrm{P}(3 \mathrm{HB})$ production increased from $0.40 \pm 0.11$ to $0.80 \pm 0.05 \mathrm{~g} / 1$ when $\mathrm{C} / \mathrm{N}$ ratio was increased from 30 to 50 . However, $\mathrm{P}(3 \mathrm{HB})$ accumulation decreased to $0.60 \pm 0.01 \mathrm{~g} / \mathrm{l}$ at the $\mathrm{C} / \mathrm{N}$ ratio of 60 . $M$. haematophila UMTKB-2 was unable to accumulate $\mathrm{P}(3 \mathrm{HB})$ at the $\mathrm{C} / \mathrm{N}$ ratio of 10 . The increment in the cell dry weight (CDW) was caused by an increase in the residual cell dry weight (RCDW). 
Table 1. Effect of various $\mathrm{C} / \mathrm{N}$ ratios on $\mathrm{P}(3 \mathrm{HB})$ production

\begin{tabular}{c|c|c|c|c}
\hline C/N ratio & $\begin{array}{c}\text { CDW } \\
{[\mathrm{g} / \mathrm{l}]}\end{array}$ & $\begin{array}{c}\mathrm{P}(3 \mathrm{HB}) \text { content } \\
{[\mathrm{wt} \%]^{\mathrm{e}}}\end{array}$ & $\begin{array}{c}\mathrm{P}(3 \mathrm{HB}) \text { concentration } \\
{[\mathrm{g} / \mathrm{l}]^{\mathrm{f}}}\end{array}$ & $\begin{array}{c}\text { RCDW } \\
{[\mathrm{g} / \mathrm{l}]}\end{array}$ \\
\hline 10 & $1.20 \pm 0.01^{\mathrm{c}}$ & $\mathrm{nd}$ & $\mathrm{nd}$ & $1.20 \pm 0.01^{\mathrm{b}}$ \\
\hline 20 & $2.30 \pm 0.11^{\mathrm{b}}$ & $24 \pm 2^{\mathrm{ab}}$ & $0.60 \pm 0.01^{\mathrm{b}}$ & $1.70 \pm 0.11^{\mathrm{a}}$ \\
\hline 30 & $1.70 \pm 0.20^{\mathrm{bc}}$ & $23 \pm 3^{\mathrm{b}}$ & $0.40 \pm 0.11^{\mathrm{c}}$ & $1.31 \pm 0.10^{\mathrm{b}}$ \\
\hline 40 & $2.20 \pm 0.10^{\mathrm{b}}$ & $26 \pm 1^{\mathrm{ab}}$ & $0.60 \pm 0.05^{\mathrm{b}}$ & $1.60 \pm 0.14^{\mathrm{a}}$ \\
\hline 50 & $2.70 \pm 0.21^{\mathrm{a}}$ & $30 \pm 1^{\mathrm{a}}$ & $0.80 \pm 0.05^{\mathrm{a}}$ & $1.90 \pm 0.05^{\mathrm{a}}$ \\
\hline 60 & $2.40 \pm 0.11^{\mathrm{ab}}$ & $25 \pm 1^{\mathrm{ab}}$ & $0.60 \pm 0.01^{\mathrm{b}}$ & $1.80 \pm 0.05^{\mathrm{a}}$ \\
\hline
\end{tabular}

$\mathrm{C} / \mathrm{N}$ - carbon to nitrogen; CDW - cell dry weight; $\mathrm{P}(3 \mathrm{HB})$ - Poly(3-hydroxybutyrate); RCDW - residual cell dry weight; nd - not detected. The data are the mean value derived from three independent repeats. ${ }^{\mathrm{a} c \mathrm{c}}$ within the same column are significantly different at $P \leq 0.05$ level (Tukey test); ${ }^{\mathrm{d}}$ the glucose concentrations $0.1 \mathrm{wt} \%, 0.3 \mathrm{wt} \%, 0.4 \mathrm{wt} \%, 0.6 \mathrm{wt} \%, 0.7 \mathrm{wt} \%$ and $0.8 \mathrm{wt} \%$ were applied to $\mathrm{C} / \mathrm{N}$ ratios $10,20,30,40,50$ and 60 respectively; ${ }^{\mathrm{e}} \mathrm{P}(3 \mathrm{HB})$ content in freeze-dried cell was analyzed by gas chromatography (GC-FID); ${ }^{\mathrm{f}} \mathrm{P}(3 \mathrm{HB})$ content multiple by $\mathrm{CDW}$

Several studies stated that relatively higher $\mathrm{P}(3 \mathrm{HB})$ concentrations were accumulated within $\mathrm{C} / \mathrm{N}$ ratios of 20-50 (Amirul et al., 2008; Wang et al., 2007). The PhaA ( $\beta$-ketothiolase enzyme) condenses acetyl-CoA into acetoacetyl-CoA, followed by reduction by $\mathrm{PhaB}$ (acetoacetyl-CoA reductase enzyme) to (R)-3-hydroxybutyryl$\mathrm{CoA}$, and polymerization into $\mathrm{P}(3 \mathrm{HB})$ by $\mathrm{PhaC}$ (PHA synthase enzyme) (Bhubalan et al., 2011). This biosynthesis pathway can be used to convert glucose into $\mathrm{P}(3 \mathrm{HB})$. Amirul and co-workers stated that the use of $\mathrm{C} / \mathrm{N}$ ratio of $>50$ had a negative effect on the bacterial growth and PHA production. The bacterial growth and PHA yield, which were $8.31 \mathrm{~g} / 1$ and $5.60 \mathrm{~g} / 1$ at the $\mathrm{C} / \mathrm{N}$ ratio of 20 decreased to $5.20 \mathrm{~g} / 1$ and $3.60 \mathrm{~g} / \mathrm{l}$ at the $\mathrm{C} / \mathrm{N}$ ratio of 50 (Amirul et al., 2008). In conclusion, the $\mathrm{C} / \mathrm{N}$ ratio of 50 was appropriate for the accumulation of $\mathrm{P}(3 \mathrm{HB})$ by M. haematophila UMTKB-2.

\section{Effect of various $3 \mathrm{HV}$ precursors on $\mathrm{P}(3 \mathrm{HB}-\mathrm{co}-3 \mathrm{HV})$ production}

We evaluated the ability of $M$. haematophila UMTKB-2 to produce $\mathrm{P}(3 \mathrm{HB}-\mathrm{co}-3 \mathrm{HV})$ copolymer from valeric acid, sodium propionate, sodium valerate, and 1-pentanol with glucose (Table 2). This strain was tested for producing other copolymers, such as $\mathrm{P}(3 \mathrm{HB}-\mathrm{co}-4 \mathrm{HB})$; however, no bacterial growth was observed when other 4-hydroxybutyrate (4HB) precursors were added (data not shown).

The use of a common $3 \mathrm{HV}$ precursor, valeric acid, contributed to the highest $3 \mathrm{HV}$ monomer composition $(91 \pm 1 \mathrm{~mol} \%)$ incorporated in the $\mathrm{P}(3 \mathrm{HB})$ homopolymer compared with other $3 \mathrm{HV}$ precursors (Table 2). This might be influenced by the alternative pathway that converted valeric acid to valery-CoA by an enzyme known as acyl-CoA synthase (Huong et al., 2017). Based on similar reports, valeryl-CoA was further converted into the (R)-3hydroxyvaleryl-CoA and finally converted to the copolymeric $3 \mathrm{HV}$ monomer unit. A similar result was reported by Bhubalan and co-workers (2008), whereby the use of valeric acid as a precursor led to a two-fold increase in the $3 \mathrm{HV}$ monomer composition. However, the acid form of this precursor inhibited bacterial growth, which was caused by the toxicity effect towards bacterial cells.

Salt-based precursors, such as sodium valerate and sodium propionate, are less toxic compared to acid-based precursors such as valeric acid (Bhubalan et al., 2008). Some bacteria, such as Burkholderia sacchari IPT $101^{\mathrm{T}}$ and Corynebacterium glutamicum, exhibited a similar increase in cell biomass when sodium propionate was supplied to the growth media (Brämer et al., 2002; Matsumoto et al., 2011). Based on the same reports, sodium propionate, when supplied to both bacteria $B$. sacchari and C. glutamicum, was converted into propionyl-CoA and then utilized in the 2-methylcitrate cycle for subsequent use by the tricarboxylic acid cycle and growth. Compared to acid-based precursors, a higher bacterial growth but a lower $3 \mathrm{HV}$ monomer composition was obtained using salt-based precursors.

To date, there has been no report on the capability of the Massilia genus for utilizing either alcohol-based precursors or alcohol-based carbon sources. This is the first study on the versatility of $M$. haematophila for accumulating copolymer using 1-pentanol, an alcohol-based 3HV 
Table 2. Effect of different precursors with glucose on $\mathrm{P}\left(3 \mathrm{HB}-c \mathrm{O}^{-} 3 \mathrm{HV}\right)$ production

\begin{tabular}{|c|c|c|c|c|c|c|}
\hline \multirow{2}{*}{ Substrate } & \multirow{2}{*}{$\begin{array}{l}\text { CDW } \\
{[\mathrm{g} / \mathrm{l}]}\end{array}$} & \multirow{2}{*}{$\begin{array}{c}\mathrm{P}(3 \mathrm{HB}-c o-3 \mathrm{HV}) \\
\text { content } \\
{[\mathrm{wt} \%]^{\mathrm{e}}}\end{array}$} & \multicolumn{2}{|c|}{ Monomer composition [mol\%] } & \multirow{2}{*}{$\begin{array}{c}\mathrm{P}(3 \mathrm{HB}-c o-3 \mathrm{HV}) \\
\text { concentration } \\
{[\mathrm{g} / \mathrm{l}]^{\mathrm{f}}}\end{array}$} & \multirow{2}{*}{$\begin{array}{c}\text { RCDW } \\
{[\mathrm{g} / \mathrm{l}]}\end{array}$} \\
\hline & & & $3 \mathrm{HB}$ & $3 \mathrm{HV}$ & & \\
\hline Valeric acid & $0.80 \pm 0.14^{\mathrm{c}}$ & $4 \pm 1^{\mathrm{b}}$ & $9 \pm 1^{\mathrm{a}}$ & $91 \pm 1^{\mathrm{a}}$ & $0.10 \pm 0.01^{\mathrm{b}}$ & $0.70 \pm 0.10^{\mathrm{c}}$ \\
\hline 1-pentanol & $3.00 \pm 0.10^{a}$ & $45 \pm 2^{\mathrm{a}}$ & $93 \pm 1^{d}$ & $7 \pm 1^{d}$ & $1.30 \pm 0.20^{\mathrm{a}}$ & $1.70 \pm 0.10^{\mathrm{a}}$ \\
\hline Sodium propionate & $1.10 \pm 0.10^{b}$ & $2 \pm 1^{\mathrm{b}}$ & $29 \pm 4^{b}$ & $74 \pm 4^{\mathrm{b}}$ & $0.10 \pm 0.01^{b}$ & $1.00 \pm 0.01^{b}$ \\
\hline Sodium valerate & $0.90 \pm 0.01^{b}$ & $3 \pm 1^{b}$ & $34 \pm 3^{c}$ & $66 \pm 3^{c}$ & $0.10 \pm 0.01^{b}$ & $0.80 \pm 0.10^{\text {bc }}$ \\
\hline
\end{tabular}

CDW - cell dry weight; $\mathrm{P}$ (3HB-co-3HV) - poly(3-hydroxybutyrate-co-3-hydroxyvalerate); 3HB - 3-hydroxybutyrate; 3HV - 3-hydroxyvalerate; $\mathrm{RCDW}$ - residual cell dry weight. The data are the mean value derived from three independent repeats. Approximately $0.64 \mathrm{wt} \%$ of glucose was added for each combination and $3 \mathrm{HV}$ precursor concentration was standardized at $0.06 \mathrm{wt} \% .{ }^{\mathrm{a}-\mathrm{d}}$ within the same column are significantly different at $P \leq 0.05$ level (Tukey test); ${ }^{e} \mathrm{P}(3 \mathrm{HB}-c o-3 \mathrm{HV})$ content in freeze-dried cell was analyzed by gas chromatography (GC-FID); ${ }_{\mathrm{f}}^{\mathrm{f}} \mathrm{P}(3 \mathrm{HB}-\mathrm{co}-3 \mathrm{HV})$ content multiple by $\mathrm{CDW}$

precursor. This strain, cultivated using 1-pentanol (3HV precursor) and glucose as the carbon sources, had achieved the highest $\mathrm{P}(3 \mathrm{HB}-\mathrm{co}-3 \mathrm{HV})$ content at $45 \pm 2 \mathrm{wt} \%$ with a copolymer concentration of $1.30 \pm 0.20 \mathrm{~g} / 1$. This is likely caused by the alcohol's relatively lower toxicity toward bacterial cells compared to other $3 \mathrm{HV}$ precursors (Shantini et al., 2013; Huong et al., 2017). For example, the use of 1-pentanol with oleic acid resulted in the production of up to $4.5 \pm 0.3 \mathrm{~g} / \mathrm{l}$ with $8 \mathrm{~mol} \%$ of $3 \mathrm{HV}$ monomer by Cupriavidus sp. USMAA2-4 (Shantini et al., 2013). In conclusion, $M$. haematophila UMTKB-2 showed a good versatility using either salt-based or alcoholbased precursors for $\mathrm{P}(3 \mathrm{HB}-c o-3 \mathrm{HV})$ copolymer accumulation.

\section{Stages of $\mathrm{P}(3 \mathrm{HB}-\mathrm{co}-3 \mathrm{HV})$ copolymer accumulation}

The incubation duration for producing $\mathrm{P}$ (3HB-co$3 \mathrm{HV})$ and overall bacterial growth was investigated. The PHA production and cell growth of most bacteria, such as Bacillus aryabhattai and Halomonas campisalis MCM B-1027, reached the stationary phase at $\sim 36 \mathrm{~h}$ when incubated using semi-optimized PHA production conditions (Kulkarni et al., 2010; Pillai et al., 2017). However, M. haematophila UMTKB-2 showed a long dormant acclimatization of up to $36 \mathrm{~h}$ for growth (below $0.50 \mathrm{~g} / \mathrm{l}$ ) and no copolymer accumulation because of the slow adaptation of this strain in the nutrient-limited media (Fig. 1). Furthermore, a rapid increase in $\mathrm{P}(3 \mathrm{HB}-\mathrm{co}$ $3 \mathrm{HV}$ ) accumulation and cell growth was observed between 48 and $84 \mathrm{~h}$. The RCDW was maintained at 1.70 $\pm 0.10 \mathrm{~g} / \mathrm{l}$ between 48 and $72 \mathrm{~h}$ with a slight decline to $1.10 \pm 0.10 \mathrm{~g} / \mathrm{l}$ at $84 \mathrm{~h}$. The accumulation of copolymer began at $48 \mathrm{~h}(1.70 \pm 0.10 \mathrm{~g} / \mathrm{l})$, and then drastically in

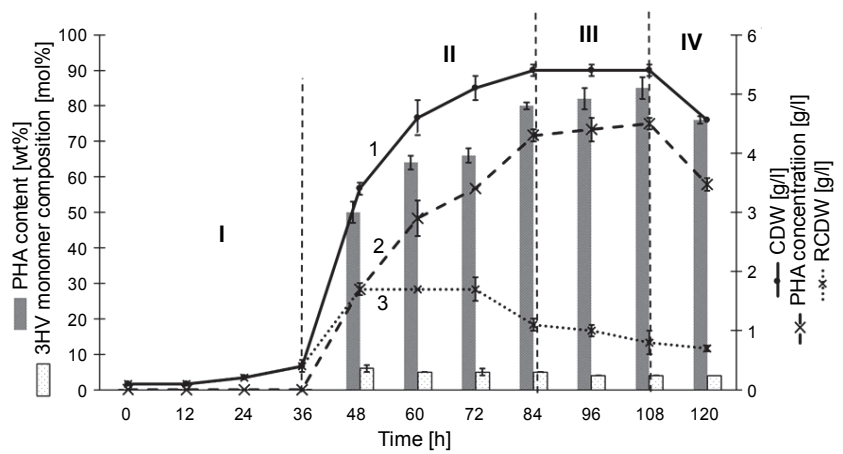

Fig. 1. Effect of incubation on $\mathrm{P}(3 \mathrm{HB}-c o-3 \mathrm{HV})$ production by M. haematophila UMTKB-2 using shaken-flask cultivation, glucose as carbon source, 1 - pentanol as $3 \mathrm{HV}$ precursor, and urea as nitrogen source; the data are the mean value derived from three independent repeats; the cultures were incubated at $200 \mathrm{rpm}$ at $30^{\circ} \mathrm{C}$; the cultures were harvested every $12 \mathrm{~h}$; I - lag phase; II - exponential phase; III - stationary phase and IV - death phase

creased until the final exponential phase at $84 \mathrm{~h}(4.2$ $\pm 0.05 \mathrm{~g} / \mathrm{l})$. Based on this result, M. haematophila UMTKB-2 was determined as a growth-associated PHAproducing bacterium and was categorized within the two major groups of PHA producers (Shabina et al., 2015).

The copolymer accumulation and cell growth reached the stationary phase between 84 and $108 \mathrm{~h}$, whereby the RCDW slightly decreased from $1.10 \pm 0.02$ to 0.80 $\pm 0.04 \mathrm{~g} / \mathrm{l}$ at 84 and $108 \mathrm{~h}$, respectively. The copolymer concentration was relatively consistent $(4.30 \pm 0.04 \mathrm{~g} / 1$ to $4.40 \pm 0.03 \mathrm{~g} / \mathrm{l})$. $M$. haematophila UMTKB-2 achieved the highest copolymer production at the stationary phase, which is similar to the results obtained by Paula and co-workers (2017) using Pandoraea sp. cultivated in crude glycerol, which achieved a higher PHA content 
Table 3. Experimental design for the optimization of $\mathrm{P}(3 \mathrm{HB}-\mathrm{co}-3 \mathrm{HV})$ as suggested by RSM

\begin{tabular}{|c|c|c|c|c|c|c|c|c|}
\hline \multirow[t]{2}{*}{ Run } & \multicolumn{2}{|c|}{$\begin{array}{c}\text { 1-pentanol } \\
\text { concentration } \\
{[\mathrm{wt} \%]}\end{array}$} & \multicolumn{2}{|c|}{$\begin{array}{l}\text { Agitation } \\
\text { [rpm] }\end{array}$} & \multicolumn{2}{|c|}{$\begin{array}{l}\text { Incubation time } \\
\qquad[\mathrm{h}]\end{array}$} & \multirow{2}{*}{$\begin{array}{l}\text { PHA concentration }{ }^{a} \\
{[\mathrm{~g} / \mathrm{l}]}\end{array}$} & \multirow{2}{*}{$\begin{array}{l}\text { 3HV monomer } \\
\text { composition }^{\text {a }} \\
\text { [mol\%] }\end{array}$} \\
\hline & A & coded & B & coded & $\mathrm{C}$ & coded & & \\
\hline 1 & 0.03 & -1 & 150 & -1 & 60 & -1 & $1.9 \pm 0.3$ & $6 \pm 0$ \\
\hline 2 & 0.09 & 1 & 150 & -1 & 60 & -1 & $1.1 \pm 0.1$ & $13 \pm 0$ \\
\hline 3 & 0.03 & -1 & 250 & 1 & 60 & -1 & $2.2 \pm 0.0$ & $3 \pm 0$ \\
\hline 4 & 0.09 & 1 & 250 & 1 & 60 & -1 & $0.5 \pm 0.1$ & $18 \pm 1$ \\
\hline 5 & 0.03 & -1 & 150 & -1 & 108 & 1 & $1.9 \pm 0.4$ & $3 \pm 0$ \\
\hline 6 & 0.09 & 1 & 150 & -1 & 108 & 1 & $2.7 \pm 0.1$ & $8 \pm 0$ \\
\hline 7 & 0.03 & -1 & 250 & 1 & 108 & 1 & $2.6 \pm 0.0$ & $3 \pm 0$ \\
\hline 8 & 0.09 & 1 & 250 & 1 & 108 & 1 & $2.3 \pm 0.1$ & $10 \pm 0$ \\
\hline 9 & 0.01 & -1.68 & 200 & 0 & 84 & 0 & $2.2 \pm 0.2$ & 0 \\
\hline 10 & 0.11 & 1.68 & 200 & 0 & 84 & 0 & $0.1 \pm 0.0$ & $52 \pm 0$ \\
\hline 11 & 0.06 & 0 & 116 & -1.68 & 84 & 0 & $2.0 \pm 0.0$ & $7 \pm 1$ \\
\hline 12 & 0.06 & 0 & 284 & 1.68 & 84 & 0 & $1.8 \pm 0.0$ & $7 \pm 1$ \\
\hline 13 & 0.06 & 0 & 200 & 0 & 44 & -1.68 & $1.8 \pm 0.1$ & $8 \pm 1$ \\
\hline 14 & 0.06 & 0 & 200 & 0 & 124 & 1.68 & $4.5 \pm 0.1$ & $5 \pm 1$ \\
\hline 15 & 0.06 & 0 & 200 & 0 & 84 & 0 & $4.2 \pm 0.1$ & $5 \pm 0$ \\
\hline 16 & 0.06 & 0 & 200 & 0 & 84 & 0 & $4.0 \pm 0.1$ & $5 \pm 0$ \\
\hline 17 & 0.06 & 0 & 200 & 0 & 84 & 0 & $4.1 \pm 0.1$ & $5 \pm 0$ \\
\hline 18 & 0.06 & 0 & 200 & 0 & 84 & 0 & $4.3 \pm 0.1$ & $5 \pm 0$ \\
\hline 19 & 0.06 & 0 & 200 & 0 & 84 & 0 & $4.3 \pm 0.1$ & $5 \pm 0$ \\
\hline 20 & 0.06 & 0 & 200 & 0 & 84 & 0 & $4.3 \pm 0.1$ & $4 \pm 0$ \\
\hline
\end{tabular}

The values given above are the average of three experiments each in triplicate conducted on different occasions.

${ }^{a}$ calculated from GC analysis

(50 wt\%) at the stationary phase of growth. The $3 \mathrm{HV}$ monomer composition slightly decreased, while the copolymer production increased during the fermentation period (Fig. 1). Moreover, as shown by Shantini (2015), lesser amounts of $3 \mathrm{HB}$ monomer were incorporated into the copolymer chains during the early phase of fermentation. By increasing the fermentation of $M$. haematophila UMTKB-2, more 3HB monomers were synthesized and the PHA concentration in bacterial cells increased. Simultaneously, the $3 \mathrm{HV}$ monomer production decreased too. This result was similar to a recent study where the $3 \mathrm{HV}$ monomer composition of the copolymer synthesized by Cupriavidus sp. USMAA2-4 declined from $25 \mathrm{~mol} \%$ at $24 \mathrm{~h}$ to $5 \mathrm{~mol} \%$ at $72 \mathrm{~h}$ (Shantini 2015).

\section{Optimization of $\mathrm{P}(3 \mathrm{HB}-\mathrm{co}-3 \mathrm{HV})$ production using the statistical design}

To maximize the production of $\mathrm{P}(3 \mathrm{HB}-\mathrm{co}-3 \mathrm{HV})$ by M. haematophila UMTKB-2, the fermentation parameters, namely, 1-pentanol concentration, agitation and incubation time, were investigated using RSM. Note that RSM had been carried out on bacterium Cupriavidus sp. USM1020 to optimize the production of $\mathrm{P}(3 \mathrm{HB}-\mathrm{co}-3 \mathrm{HV})$ using similar variables, i.e., 1-pentanol concentration and incubation time (Bhubalan et al., 2008). The responses that were tested using RSM included PHA concentration and $3 \mathrm{HV}$ monomer composition. The ranges of the variables varied for 1-pentanol concentration $(0.01-0.11 \mathrm{wt} \%)$, agitation rate (116-284 rpm), and incubation time (44-124 h). 
Table 4. Analysis of variance (ANOVA) and regression analysis for PHA concentration and 3HV monomer composition in RSM

\begin{tabular}{|c|c|c|c|c|c|c|}
\hline Response & Source & $\begin{array}{c}\text { Sum } \\
\text { of squares }\end{array}$ & Df & $\begin{array}{l}\text { Mean } \\
\text { square }\end{array}$ & $F$ value & $\begin{array}{c}P \text {-value } \\
P>F\end{array}$ \\
\hline \multirow{10}{*}{$\begin{array}{c}\text { PHA } \\
\text { concentration } \\
{[\mathrm{g} / \mathrm{l}]}\end{array}$} & model & 45.61 & 5 & 5.70 & 19.60 & $<0.0001$ (significant) \\
\hline & A: 1 -pentanol concentration & 2.20 & 1 & 2.20 & 7.56 & 0.0189 \\
\hline & C: incubation time & 6.18 & 1 & 6.18 & 21.25 & 0.0008 \\
\hline & $\mathrm{A}^{2}$ & 22.82 & 1 & 22.82 & 78.45 & $<0.0001$ \\
\hline & $\mathrm{B}^{2}$ & 14.94 & 1 & 14.94 & 51.34 & $<0.0001$ \\
\hline & $\mathrm{C}^{2}$ & 3.26 & 1 & 3.26 & 11.19 & 0.0065 \\
\hline & residual & 3.20 & 11 & 0.29 & - & - \\
\hline & lack of fit & 1.43 & 6 & 0.24 & 0.828 & 0.6813 (not significant) \\
\hline & pure error & 1.77 & 5 & 0.35 & - & - \\
\hline & total & 48.81 & 19 & - & - & - \\
\hline \multirow{7}{*}{$\begin{array}{c}3 \mathrm{HV} \\
\text { monomer } \\
\text { composition } \\
{[\mathrm{wt} \%]}\end{array}$} & model & 1581.75 & 2 & 790.88 & 10.65 & $<0.0001$ (significant) \\
\hline & A: 1-pentanol concentration & 1021.11 & 1 & 1021.11 & 94.37 & $<0.0001$ \\
\hline & $\mathrm{A}^{2}$ & 560.64 & 1 & 560.64 & 6.24 & 0.0006 \\
\hline & residual & 537.05 & 17 & 31.59 & - & - \\
\hline & lack of fit & 2.03 & 12 & 1.03 & 0.03 & 0.1101 (not significant) \\
\hline & pure error & 1.50 & 5 & 0.30 & - & - \\
\hline & total & 2118.80 & 19 & - & - & - \\
\hline
\end{tabular}

$\mathrm{R}^{2}(\mathrm{RCDW})=0.9273 ; \mathrm{R}^{2}(\mathrm{PHA}$ concentration $)=0.9344 ; \mathrm{R}^{2}(3 \mathrm{HV}$ monomer $)=0.9010 ; \mathrm{Df}$ - degree of freedom; $F-$ variance ratio; $P$ - probability

In Table 3, the results on 20 experiment runs in RSM are presented. To define the significance of the threeresponse model, ANOVA was performed and the data are shown in Table 4 . The model was highly significant as evident from a low probability value $(P>F)$, which is $<0.0001$ for both $3 \mathrm{HV}$ monomer composition and PHA concentration. Furthermore, the "Lack-of-fit $F$ value" for the 3HV monomer composition and PHA concentration were 0.030 and 0.828 , respectively, which indicated that all lack-of-fit values were insignificant relative to pure error. The ANOVA clearly indicated that all models had effectively fitted the experimental data. The coefficient $\mathrm{R}^{2}$ was used to determine the goodness-of-fit of the model. For all the responses, $R^{2}$ was more than $90 \%$, which indicated that this experiment was reliable.

The RSM generated the following regression equations with the responses and tested variables in the coded unit irrespective of their significance:

PHA concentration $=4.96-0.40 \mathrm{~A}-0.033 \mathrm{~B}+0.67 \mathrm{C}-$

$$
\begin{aligned}
& +0.25 \mathrm{AB}+0.39 \mathrm{AC}+0.073 \mathrm{BC}- \\
& +1.26 \mathrm{~A}^{2}-1.02 \mathrm{~B}^{2}-0.48 \mathrm{C}^{2}
\end{aligned}
$$

$$
\begin{aligned}
3 \mathrm{HV} \text { monomer } & =4.67+8.65 \mathrm{~A}+0.29 \mathrm{~B}-1.54 \mathrm{C}+ \\
& +1.25 \mathrm{AB}-1.25 \mathrm{AC}-9.465 \mathrm{E}^{-16} \mathrm{BC}+ \\
& +6.12 \mathrm{~A}^{2}-0.24 \mathrm{~B}^{2}-0.42 \mathrm{C}^{2}
\end{aligned}
$$

The terms A, B, and C represent the coded factors of 1-pentanol concentration, agitation and incubation time, respectively. Moreover, the $3 \mathrm{D}$ response surface is a relatively visual representation to study the interaction between variables and responses. Figure 2 shows the 3D response surfaces for the PHA concentration and $3 \mathrm{HV}$ monomer composition.

Elliptical 3D surface graphs show a high interaction of 1-pentanol concentration, agitation and incubation time against PHA concentration (Fig. 2A, Fig. 2B and Fig. 2C). The PHA concentration increased as the 1-pentanol concentration and agitation increased from 0.03 to $0.06 \mathrm{wt} \%$ and from 150 to $200 \mathrm{rpm}$, respectively. The copolymer yield started to level off as the 1-pentanol concentration and agitation were further increased. This was probably because high 1-pentanol concentration had a negative effect on the copolymer production, as reported previously (Berezina, 2012). Moreover, high agita- 
A
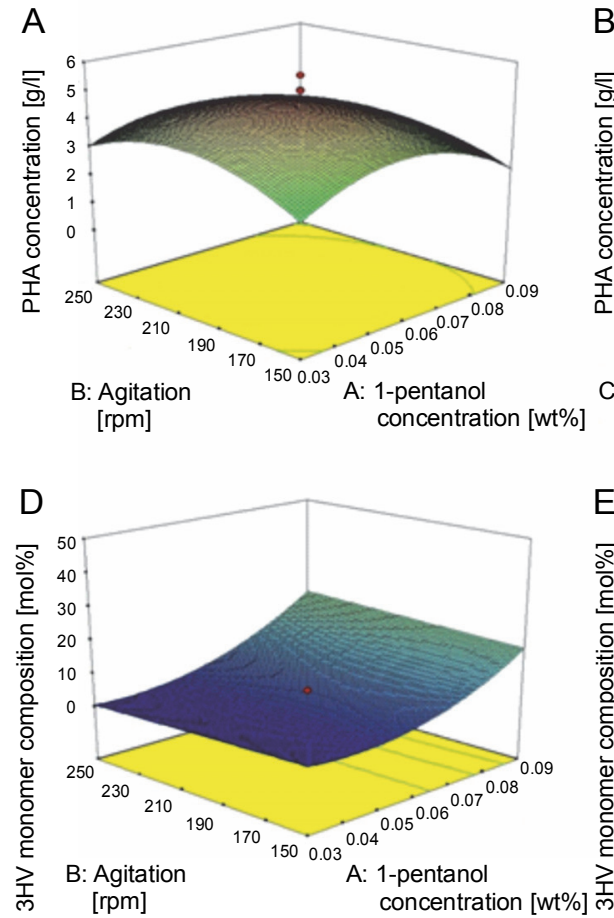

B

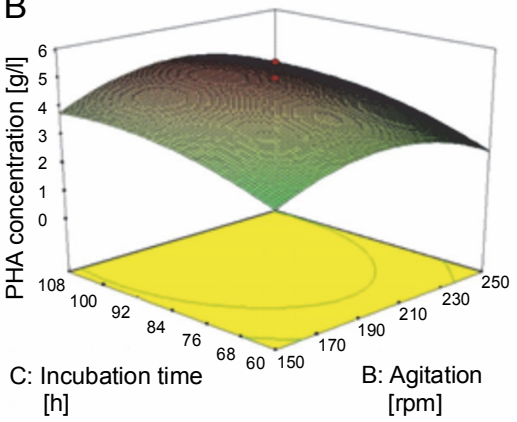

$E$

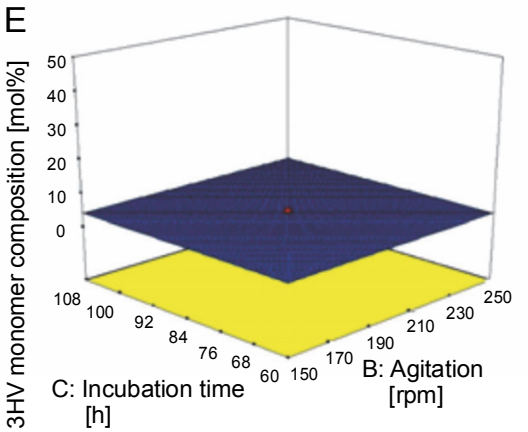

C

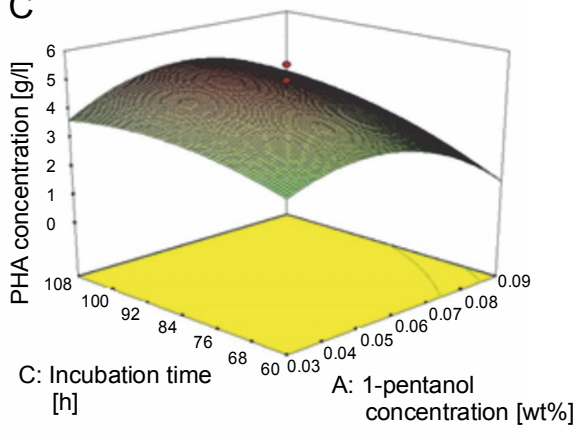

$\mathrm{F}$

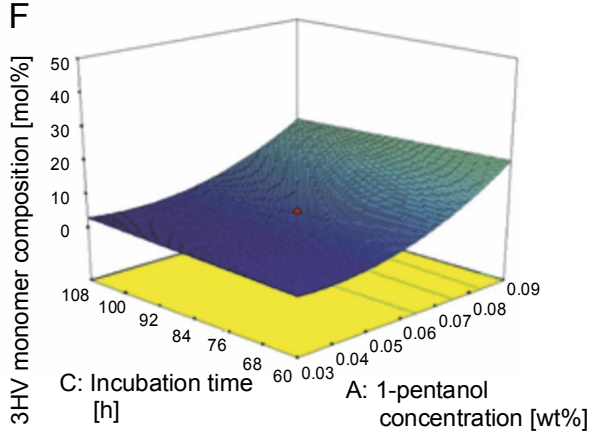

Fig. 2. The 3D surface graphs generated by RSM: response toward PHA concentration (A-C) and 3HV monomer composition (D-F); the interaction effect of: differenced 1-pentanol concentration and agitation at $84 \mathrm{~h}(\mathrm{~A}$ and $\mathrm{D})$, differenced incubation time and agitation at $0.06 \mathrm{wt} \% 1$ - pentanol concentration (B and $\mathrm{E}$ ) and differenced 1-pentanol concentration and incubation time at $200 \mathrm{rpm}(\mathrm{C}$ and $\mathrm{F})$

tion negatively affected copolymer production. Agitation can be studied as a parameter that influences the amount of dissolved oxygen in shaken-flask cultures, and the aggregation or shearing of bacterial cells (Zhou et al., 2018). According to Baei et al. (2010), high agitation rates caused a high shear force that disturbed the formation of PHA granules in the bacterial cells. Furthermore, a decreased PHA productivity was reported with agitation rates of $>220 \mathrm{rpm}$ despite the increased bacterial growth (Alsafadi and Mashaqbeh, 2017; Kynadi and Suchithra, 2017). However, agitation rates below the optimal level caused cell aggregation and a heterogeneous culture media (Musa et al., 2016). Furthermore, agitation was used as an optimisation parameter of PHA production in several studies (Aramvash et al., 2015; Geethu et al., 2019).

Increasing the concentration of 1-pentanol from 0.03 to $0.09 \mathrm{wt} \%$ considerably increased the $3 \mathrm{HV}$ monomer composition, but the latter was unaffected by agitation or incubation time (Fig. 2D, Fig. 2E and Fig. 2F). The 3HV monomer composition that had been increased by elevating the 1-pentanol concentration could be because of the enzyme expression or $\mathrm{pH}$. One of the enzymes, 3-ketothiolase, led to the formation of 3-ketovaleryl-CoA. A higher expression of 3-ketothiolase could lead to a higher amount of $3 \mathrm{HV}$ monomer (Shantini et al., 2013). Other than the enzyme expression, $\mathrm{pH}$ has been known to affect the monomer composition of the copolymer at certain levels (Salim et al., 2011).

To verify the RSM-based model constructed using RSM, the verification experiment was triplicated according to the optimized conditions provided by the Design Expert program (Table 5). The RSM statistical tool processed using the Design Expert predicted that, under optimal conditions, the maximum PHA concentration and $3 \mathrm{HV}$ monomer composition would be $4.34 \mathrm{~g} / 1$ and $6 \mathrm{~mol} \%$ using the recommended optimized conditions. Subsequently, the validity test revealed that the PHA concentration had a difference of $0.7 \mathrm{~g} / 1$ between the predicted and actual values, which was 4.34 and $5 \mathrm{~g} / \mathrm{l}$, respectively (Table 5). Zafar and co-workers (2012) reported a difference of $1.3 \mathrm{~g} / \mathrm{l}$ between the actual and predicted PHA concentrations using the RSM statistical tool. In other studies, a slight difference has been ob- 
Table 5. PHA concentration and $3 \mathrm{HV}$ monomer composition before and after optimization of conditions

\begin{tabular}{|c|c|c|c|c|c|c|c|c|}
\hline \multicolumn{3}{|l|}{ Variables } & \multicolumn{3}{|c|}{$\begin{array}{l}\text { PHA concentration } \\
{[\mathrm{g} / \mathrm{l}]}\end{array}$} & \multicolumn{3}{|c|}{$\begin{array}{l}\text { 3HV monomer composition } \\
{[\mathrm{mol} \%]}\end{array}$} \\
\hline & \multirow{2}{*}{ before $^{c}$} & \multirow{2}{*}{$\operatorname{after}^{\mathrm{d}}$} & \multirow{2}{*}{ before } & \multicolumn{2}{|c|}{ after } & \multirow{2}{*}{ before } & \multicolumn{2}{|c|}{ after } \\
\hline & & & & predicted $^{\mathrm{e}}$ & actual $^{\mathrm{f}}$ & & predicted $^{\mathrm{e}}$ & actual $^{\mathrm{f}}$ \\
\hline 1-pentanol concentration [wt\%] & 0.06 & 0.07 & & & & & & \\
\hline $\begin{array}{l}\text { Agitation }[\mathrm{rpm}] \\
\text { Incubation time }[\mathrm{h}]\end{array}$ & $\begin{array}{l}200 \\
108\end{array}$ & $\begin{array}{l}176 \\
122\end{array}$ & $4.40 \pm 0.03^{b}$ & 4.34 & $5.00 \pm 0.04^{\mathrm{a}}$ & $4^{\mathrm{b}}$ & 6 & $7^{\mathrm{a}}$ \\
\hline
\end{tabular}

RCDW - residual cell dry weight; 3HV - 3-hyroxyvalerate; ${ }^{\text {ab }}$ within the same column are significantly different at $P \leq 0.05$ level (Tukey test); ${ }^{c}$ conditions before optimization; ${ }^{\mathrm{d}}$ conditions after optimization; ${ }^{\mathrm{e}}$ predicted value generated by software; ${ }^{\mathrm{f}}$ actual value; the data shown are the average of 3 replicates

Table 6. Mechanical and thermal properties of polymers

\begin{tabular}{|c|c|c|c|c|c|c|c|}
\hline \multirow[b]{3}{*}{ Polymer } & \multicolumn{7}{|c|}{ Properties } \\
\hline & \multicolumn{3}{|c|}{ mechanical $^{\mathrm{f}}$} & \multicolumn{4}{|c|}{ thermal $^{g}$} \\
\hline & $\begin{array}{l}\text { tensile } \\
\text { strength } \\
{[\mathrm{MPa}]}\end{array}$ & $\begin{array}{l}\text { Young's } \\
\text { modulus } \\
{[\mathrm{MPa}]}\end{array}$ & $\begin{array}{c}\text { elongation } \\
\text { of break } \\
{[\%]}\end{array}$ & $\begin{array}{c}\text { melting } \\
\text { temperature } \\
{\left[T_{m}{ }^{\circ} \mathrm{C}\right]}\end{array}$ & $\begin{array}{c}\text { glass transition } \\
\text { temperature } \\
{\left[T_{g}{ }^{\circ} \mathrm{C}\right]}\end{array}$ & $\begin{array}{c}H_{\mathrm{m}} \\
{[\mathrm{J} / \mathrm{g}]}\end{array}$ & $\begin{array}{c}\text { crystallinity }^{\mathrm{h}} \\
{[\%]}\end{array}$ \\
\hline $\mathrm{P}(3 \mathrm{HB})$ & $17 \pm 1^{\mathrm{b}}$ & $239 \pm 7^{b}$ & $7 \pm 1^{\mathrm{b}}$ & $172 \pm 1^{\mathrm{a}}$ & $6.9 \pm 0.1^{\mathrm{a}}$ & $65.4 \pm 1.0^{\mathrm{a}}$ & $46 \pm 1^{a}$ \\
\hline $\mathrm{P}(3 \mathrm{HB}-c o-7 \mathrm{~mol} \% 3 \mathrm{HV})^{\mathrm{i}}$ & $11 \pm 1^{\mathrm{c}}$ & $97 \pm 6^{c}$ & $13 \pm 1^{a}$ & $149 \pm 1^{c}$ & $4.4 \pm 0.2^{b}$ & $48.7 \pm 1.0^{c}$ & $34 \pm 1^{b}$ \\
\hline $\mathrm{P}(3 \mathrm{HB}-\mathrm{co}-6 \mathrm{~mol} \% 3 \mathrm{HV})^{\mathrm{j}}$ & $25 \pm 2^{\mathrm{a}}$ & $196 \pm 12^{d}$ & $8 \pm 1^{b}$ & $167^{\mathrm{b}}$ & $-7^{\mathrm{c}}$ & $46^{\mathrm{b}}$ & $33^{\mathrm{b}}$ \\
\hline $\mathrm{P}(3 \mathrm{HB}-\mathrm{co}-24 \mathrm{~mol} \% 3 \mathrm{HV})^{\mathrm{j}}$ & $14^{\mathrm{c}}$ & $1300^{\mathrm{a}}$ & NA & $140^{\mathrm{d}}$ & $-12^{d}$ & NA & NA \\
\hline
\end{tabular}

NA - not available; $\mathrm{P}(3 \mathrm{HB})$ - poly(3-hydroxybutyrate); $\mathrm{P}\left(3 \mathrm{HB}-\right.$ co-3HV) - poly(3-hydroxybutyrate-co-3-hydroxyvalerate); ${ }^{\text {a-e }}$ within the same column are significantly different at $P \leq 0.05$ level (Tukey test); ${ }^{\mathrm{f}}$ mechanical properties were determined by using tensile machine (the data shown are the average of 10 replicates); ${ }^{g}$ thermal properties were determined by using DSC (the data shown are the average of 3 replicates); ${ }_{\mathrm{h}}^{\mathrm{h}}$ percentage of crystallinity was calculated based on Gumel et al. (2012); ${ }^{\mathrm{i}}$ data obtained from the post-optimized copolymer of this study; j data obtained from Shantini et al. (2013)

served; hence, the value gap obtained in this study was considered as normal. Using optimized conditions with the RSM statistical tool, the actual PHA yield produced was higher than the predicted PHA yield.

Furthermore, the result from the optimal conditions was compared to the result from the OFAT method (unoptimized conditions). After optimization using RSM, a $14 \%$ increment was observed of PHA concentration from $4.40 \pm 0.03 \mathrm{~g} / 1$ to $5.00 \pm 0.04 \mathrm{~g} / \mathrm{l}$. Moreover, the $0.01 \mathrm{wt} \%$ increase of 1-pentanol supply, as suggested by the software, had accumulated copolymer with approximately twofold increment of $3 \mathrm{HV}$ monomer composition from 4 to $7 \mathrm{~mol} \%$. However, in this study, the $3 \mathrm{HV}$ monomer composition obtained achieved a two-fold increase that was higher than the result obtained by Huong and coworkers who observed a decrease in 3HV monomer composition after RSM optimization (Huong et al., 2017).

\section{Characteristics of the PHA produced by UMTKB-2}

The properties of $\mathrm{P}(3 \mathrm{HB}-\mathrm{co}-7 \mathrm{~mol} \% 3 \mathrm{HV})$ copolymer produced by Massilia haematophila have been examined in this study. The polymeric randomness was determined by carbonyl resonance, which split into four peaks according to the dial sequences of $\mathrm{B}^{*} \mathrm{~B}, \mathrm{~V}^{*} \mathrm{~V}$, and $\mathrm{B}^{*} \mathrm{~V}+$ $\mathrm{V}^{*} \mathrm{~B}$ (Kynadi and Suchithra, 2017). The dyad sequence distributions for the $F_{B B}, F_{B V}, F_{V B}$, and $F_{V V}$ values of the copolymer were $0.8288,0.0650,0.0736$, and 0.0255 , respectively. As expected, the result showed that $\mathrm{P}(3 \mathrm{HB}$ co-7 mol\% $3 \mathrm{HV}$ ) was a block copolymer, which corresponded with two studies whereby, similar block copolymers were synthesized using Paracoccus denitrificans ATTC 17741 (Chanprateep et al., 2006) and Cupriavidus sp. USMAA2-4 (Shantini, 2015). The P(3HB-co$3 \mathrm{HV}$ ) that has more than $7 \mathrm{~mol} \%$ of $3 \mathrm{HV}$ units was determined as a random copolymer, in agreement with most studies (Žagar and Kržan, 2009; Han et al., 2015). 
Table 6 shows the mechanical and thermal properties of the polymers. The $T_{\mathrm{m}}$ of the $\mathrm{P}(3 \mathrm{HB}-\mathrm{co}-3 \mathrm{HV})$ copolymers of this study fell in a normal range between 150 and $160^{\circ} \mathrm{C}$ (Allen et al., 2010). According to Table 6, both $T_{\mathrm{m}}$ and $T_{\mathrm{g}}$ decreased in the following order, which was inversely correlated with the $3 \mathrm{HV}$ monomer composition: $\mathrm{P}(3 \mathrm{HB}-\mathrm{co}-24 \mathrm{~mol} \% 3 \mathrm{HV})<\mathrm{P}(3 \mathrm{HB}-c o-7 \mathrm{~mol} \% 3 \mathrm{HV})$ $<\mathrm{P}(3 \mathrm{HB})$. The copolymer in this study had a $T_{\mathrm{m}}$ that was lower than $160^{\circ} \mathrm{C}$; hence, it was considered as a stable polymer with reduced thermal degradation of molecular weight for better processing in industrial applications such as packaging (Bhati and Mallick, 2012). Moreover, the elastomeric properties of the copolymer increased because of the large volume of molecular movement that increased mobility in the amorphous state (Bhati and Mallick, 2012).

By incorporating $7 \mathrm{~mol} \%$ of $3 \mathrm{HV}$ monomers, the copolymers showed a significant decrease in the percentage of crystallinity ( $34 \pm 1 \%$ ) compared to $\mathrm{P}(3 \mathrm{HB})$ $(46 \pm 1 \%)$. The copolymers with a lower percentage of crystallinity showed a lower $H_{\mathrm{m}}$ value (Table 6). This is because of the slower rate of crystal growth and nucleation in copolymers as the ethyl side chains of $3 \mathrm{HV}$ monomer units acted as an obstruction to the $\mathrm{P}(3 \mathrm{HB})$ lattice, thus increasing the lattice dimension (Kunioka et al., 1989). In the current study, the percentage of polymer crystallinity was half of the values reported by Silva and co-workers (2005), which was $62-64 \%$ for the polymers that contained $0-8 \mathrm{~mol} \%$ of $3 \mathrm{HV}$ monomer, respectively.

Furthermore, the crystallization process influenced the mechanicalproperties of the copolymer (Pena etal., 2014). The $\mathrm{P}(3 \mathrm{HB}-\mathrm{co}-3 \mathrm{HV}$ ) comprising $>30 \mathrm{~mol} \%$ of $3 \mathrm{HV}$ monomer showed isomorphism properties (Liu et al., 2014); hence, no isomorphism occurred in $\mathrm{P}(3 \mathrm{HB}-\mathrm{co}-7 \mathrm{~mol} \%$ $3 \mathrm{HV})$. Furthermore, the mechanical properties of the polymer were affected by $T_{\mathrm{g}}$. In this study, the polymeric tensile strength observed decreased by $6 \mathrm{MPa}$ when $T_{\mathrm{g}}$ decreased by $\sim 3^{\circ} \mathrm{C}$ (Table 6 ), which indicated that the copolymer became softer and more flexible compared to $\mathrm{P}(3 \mathrm{HB})$. Zakaria and co-workers (2013) stated that a tensile strength of $14 \mathrm{MPa}$, which is close to the tensile strength $(11 \mathrm{MPa})$ of $\mathrm{P}(3 \mathrm{HB}-\mathrm{co}-7 \mathrm{~mol} \% 3 \mathrm{HV})$, was observed for $\mathrm{P}(3 \mathrm{HB}-c o-7 \mathrm{~mol} \% 3 \mathrm{HV})$ synthesized in this study.

\section{Conclusions}

This is the study to report the PHA-producing ability of the species and strain, $M$. haematophila UMTKB-2.
This brackish-water isolate was able to synthesize the block $\mathrm{P}(3 \mathrm{HB}-\mathrm{co}-3 \mathrm{HV})$ copolymer with the $3 \mathrm{HV}$ comonomer using alcohol-based or acid-based 3HV precursors, as well as glucose as a carbon source. M. haematophila UMTKB-2 demonstrated good versatility for utilizing an alcohol-based precursor, 1-pentanol, to produce $\mathrm{P}(3 \mathrm{HB}$ co-3HV). The condition optimization of PHA production through statistical modeling successfully increased the accumulation of $\mathrm{P}(3 \mathrm{HB}-\mathrm{co}-3 \mathrm{HV})$ in terms of $\mathrm{PHA}$ concentration and $3 \mathrm{HV}$ monomer composition. The optimization almost doubled the $3 \mathrm{HV}$ monomer composition and increased the copolymer production by $14 \%$. The optimal conditions to produce $\mathrm{P}(3 \mathrm{HB}-\mathrm{co}-3 \mathrm{HV})$ from this strain are as follows: $0.07 \mathrm{wt} \%$ of 1-pentanol, $176 \mathrm{rpm}$ agitation rate, and $122 \mathrm{~h}$ of incubation time. Moreover, this strain and species had been reported to produce $\mathrm{P}(3 \mathrm{HB})$ in a previous study (Kiun et al., 2016).

\section{Acknowledgments}

The present research was supported by the National Institutes of Biotechnology Malaysia, Malaysian Institute of Pharmaceuticals and Nutraceuticals [Grant number 02-05-23-SF0023] and K.J.T. is grateful for the MyMaster scholarship awarded by the Ministry of Education, Malaysia.

\section{References}

Aghjeh S.D., Aramvash A. (2015) One-factor-at-a-time optimization of polyhydroxybutyrate production and growth of Alcaligenes eutrophus by altering culture parameters and incubation time. J. Sci. Islam. Republ. Iran 26: 303-313.

Alsafadi D., Mashaqbeh O. (2017) A one-stage cultivation process for the production of poly-3-(hydroxybutyrate-co-hydroxyvalerate) from olive mill wastewater by Haloferax mediterranei. New Biotechnol. 34: 47-53.

Allen A.D., Anderson W.A., Ayorinde F.O., Eribo B.E. (2010) Biosynthesis and characterization of copolymer poly(3HB-co$3 H V)$ from saponified Jatropha curcas oil by Pseudomonas oleovorans. J. Ind. Microbiol. Biotechnol. 37: 849-856.

Amirul A.A., Yahya A.R.M., Sudesh K., Azizan M.N.M., Majid M.I.A. (2008) Biosynthesis of poly(3-hydroxybutyrate-co4-hydroxybutyrate) copolymer by Cupriavidus sp. USMAA1020 isolated from Lake Kulim, Malaysia. Bioresour. Technol. 99: 4903-4909.

Aramvash A., Shahabi Z.A., Aghjeh S.D., Ghafari M.D. (2015) Statistical physical and nutrient optimization of bioplastic polyhydroxybutyrate production by Cupriavidus necator. Int. J. Environ. Sci. Technol. 12: 2307-2316.

Baei M.S., Najafpour G.D., Lasemi Z., Tabandeh F., Younesi H., Issazadeh H., Khodabandeh M. (2010) Optimization PHAs production from dairy industry wastewater (Cheese Whey) by Azohydromonas lata DSMZ 1123. Iran. J. Energy Environ. 1: 132-136. 
Bassas-Galia M., Nogales B., Arias S., Rohde M., Timmis K.N., Molinari G. (2012) Plant original Massilia isolates producing polyhydroxybutyrate, including one exhibiting high yields from glycerol. J. Appl. Microbiol. 112: 443-454.

Berezina N. (2012) Enhancing the 3-hydroxyvalerate component in bioplastic PHBV production by Cupriavidus necator. Biotechnol. J. 7: 304-309.

Bhati R., Mallick N. (2012) Production and characterization of poly(3-hydroxybutyrate-co-3-hydroxyvalerate) co-polymer by a N2-fixing cyanobacterium, Nostoc muscorum Agardh. J. Chem. Technol. Biotechnol. 87: 505-512.

Bhubalan K., Chee J.Y., Sudesh K. (2011) Prospect and sustainable production of polyhydroxyalkanoate from palm oil. [in:] Bioprocess sciences and technology. Ed. Liong M.T., USA, Nova Science Publishers: 55-84.

Bhubalan K., Lee W.H., Loo C.Y., Yamamoto T., Tsuge T., Doi Y., Sudesh K. (2008) Controlled biosynthesis and characterization of poly(3-hydroxybutyrate-co-3-hydroxyvalerateco-3-hydroxyhexanoate) from mixtures of palm kernel oil and 3HV-precursors. Polym. Degrad. Stab. 93: 17-23.

Brämer C., Silva L.F., Gomez J.G., Priefert H., Steinbuchel A. (2002) Identification of the 2-methylcitrate pathway involved in the catabolism of propionate in the polyhydroxyalkanoate-producing strain. Microbiology 68: 271-279.

Braunegg G., Sonnleitner B., Laffer R.M. (1978) A rapid gas chromatographic method for the determination of Poly- $\beta$ hydroxybutyri acid in microbial biomass. Eur. J. Appl. Microbiol. Biotechnol. 6: 29-37.

Cerrone F., Peinado M.D.M.S., Díaz M.R., López J.G., Pozo C. (2012) PHAs production by strains belonging to Massilia genus from starch. Starch 63: 236-240.

Chanprateep S., Shimizu H., Shioya S. (2006) Characterization and enzymatic degradation of microbial copolyester $P(3 H B-c o-3 H V)$ s produced by metabolic reaction modelbased system. Polym. Degrad. Stab. 91: 2941-2950.

Doi Y. (1995) Microbial synthesis, physical properties, and biodegradability of polyhydroxyalkanoates. Macromol. Symp. 98: 585-599.

Geethu M., Vrundha R., Chandrashekar H.R., Divyashree M.S. (2019) Improvement of the production and characterisation of polyhydroxyalkanoate by Bacillus endophyticus using inexpensive carbon feedstock. J. Polym. Environ. https://doi.org/10.1007/s10924-019-01397-z

Han J., Wu L.P., Hou J., Zhao D., Xiang H. (2015) Biosynthesis, characterization, and hemostasis potential of tailor-made poly(3-hydroxybutyrate-co-3-hydroxyvalerate) produced by Haloferax mediterranei. Biomacromolecules 16: 578-588.

Han X., Satoh Y., Kuriki Y., Seino T., Fujita S., Suda T. et al. (2014) Polyhydroxyalkanoate production by a novel bacterium Massilia sp. UMI-21 isolated from seaweed, and molecular cloning of its polyhydroxyalkanoate synthase gene. J. Biosci. Bioeng. 118: 514-519.

Huong K.H., Shantini K., Lim S.Y.H., Amirul A.A. (2015) Biosynthetic enhancement of single-stage poly(3-hydroxybutyrate-co-4-hydroxybutyrate) production by manipulating the substrate mixtures. J. Ind. Microbiol. Biotechnol. 42: 1291-1297.
Huong K.H., Shantini K., Sharmini R., Amirul A.A. (2017) $E_{X}$ ploring the potential of 1-pentanol and oleic acid for optimizing the production of poly(3-hydroxybutyrate-co-3hydroxyvalerate) copolymer by Cupriavidus sp. USMAA1020. Arab J. Sci. Eng. 42: 2313-2320.

Jambeck J.R., Geyer R., Wilcox C., Siegler T.R., Peryman M., Andrady A., Narayan R., Law K.L. (2015) Plastic waste inputs from land into the ocean. Science 347: 768-771.

Kamiya N., Yamamoto Y., Inoue Y., Chiib R., Doi Y. (1989) Microstructure of bacterially synthesized poly(3-hydroxybutyrate-co-3-hydroxyvalerate. Macromolecules 22: 1676-1682.

Kampfer P., Falsen E., Busse H.J. (2008) Naxibacter varians sp. nov. and Naxibacter haematophilus sp. nov., and emended description of the genus Naxibacter. Int. J. Syst. Evol. Microbiol. 58: 1680-1684.

Kampfer P., Lodders N., Martin K., Falsen E. (2011) Revision of the genus Massilia La Scola et al. 2000, with an emended description of the genus and inclusion of all species of the genus Naxibacter as new combinations, and proposal of Massilia consociata sp. nov. Int. J. Syst. Evol. Microbiol. 61: 1528-1533.

Kiun J.T., Bhubalan K., Amirul A.A. (2016) Novel PHA bioplastic producing bacteria isolated from brackish environment. [in:] The 14th Symposium of Malaysian Society of Applied Biology. Ed. Ibrahim N., Ryadi H., Dyari E., Sairi F., Liew W.Y.P., Ali M.M., Omar R., Malacca: The Malaysian Society of Applied Biology: 149-155.

Koller M., Salerno A., Strohmeier K., Schober S., Mittelbach M., Illieva V., Chiellini E., Braunegg G. (2014) Novel precursors for production of 3-hydroxyvalerate-containing poly[(R)-hydroxyalkanoate]s. Biocatal. Biotransformation 32: 161-167.

Kourmentza C., Plácido J., Venetsaneas N., Figols A.B., Varrone C., Gavala H.N., Reis M.A.M. (2017) Recent advances and challenges towards sustainable polyhydroxyalkanoate (PHA) production. Bioengineering 4: 55.

Kulkarni S.O., Kanekar P.P., Nilegaonkar S.S., Sarnaik S.S., Jog J.P. (2010) Production and characterization of a biodegradable poly (hydroxybutyrate-co-hydroxyvalerate) (PHB-co-PHV) copolymer by moderately haloalkalitolerant Halomonas campisalis MCM B-1027 isolated from Lonar Lake, India. Bioresour. Technol. 101: 9765-9771.

Kunioka M., Tamaki A., Doi Y. (1989) Crystalline and thermal properties of bacterial copolyesters: poly(3-hydroxybutyrate-co-3-hydroxyvalerate) and poly(3-hydroxybutyrate-co-4 hydroxybutyrate). Macromolecules 22: 694-697.

Kynadi A.S., Suchithra T.V. (2017) Formulation and optimization of a novel media comprising rubber seed oil for PHA production. Ind. Crops Prod. 105: 156-163.

Lee S.Y., Choi J.I., Wong H.H. (1999) Recent advances in polyhydroxyalkanoate production by bacterial fermentation: mini-review. Int. J. Biol. Macromol. 25: 31-36.

Liu Q., Zhang H., Deng B., Zhao X. (2014) Poly (3-hydroxybutyrate-co-3-hydroxyvalerate): structure, property, and fiber. Int. J. Polym. Sci. 2014: 3-11. 
Loo C., Sudesh K. (2007) Polyhydroxyalkanoates: bio-based microbial plastics and their properties. MPJ 2: 31-57.

Matsumoto K., Kitagawa K., Jo S.J., Song Y., Taguchi S. (2011) Production of poly(3-hydroxybutyrate-co-3-hydroxyvalerate) in recombinant Corynebacterium glutamicum using propionate as a precursor. J. Biotechnol. 152: 144-146.

Morshedi A., Akbarian M. (2014) Application of response surface methodology: design of experiments and optimization: a mini review. JLS 4: 2434-2439.

Musa H., Bolanle B.B., Kasim F.H., Arbain D. (2016) Screening and production of polyhydroxybutyrate (PHB) by bacterial strains isolated from rhizosphere soil of groundnut plants. Sains Malaysiana 45: 1469-1476.

Narayanan A., Ramana K.V. (2012) Polyhydroxybutyrate production in Bacillus mycoides DFC1 using response surface optimization for physico-chemical process parameters. 3 Biotech 2: 287-296.

Paula F.C.D., Kakazu S., Paula C.B.C.D., Gomez J.G.C., Contiero J. (2017) Polyhydroxyalkanoate production from crude glycerol by newly isolated Pandoraea sp. JKSUS 29: 166-173.

Pena C., Castillo T., Garcia A., Millan M., Segura D. (2014) Biotechnological strategies to improve production of microbial poly-(3-hydroxybutyrate): A review of recent research work. Microb. Biotechnol. 7: 278-293.

Pillai A.B., Jaya Kumar A., Thulasi K., Kumarapillai H. (2017) Evaluation of short-chain-length polyhydroxyalkanoate accumulation in Bacillus aryabhattai. Braz. J. Microbiol. 48: 451-460.

Salim Y.S., Abdullah A.A.A., Nasri C.S.S.M., Ibrahim M.N.M. (2011) Biosynthesis of poly(3-hydroxybutyrate-co-3-hydroxyvalerate) and characterisation of its blend with oil palm empty fruit bunch fibers. Bioresour. Technol. 102: 3626-3628.

Shabina M., Afzal M., Hameed S. (2015) Bacterial polyhydroxyalkanoates-eco-friendly next generation plastic: production, biocompatibility, biodegradation, physical properties and applications. Green Chem. Lett. Rev. 8: 56-77.

Shantini K. (2015) Optimized production of Poly(3-hydroxybutyrate-co-3-hydroxyvalerate) from Cupriavidus sp. USMAA2-4 and its characterization. Ph.D Thesis: Universiti Sains Malaysia.

Shantini K., Bhubalan K., Yahya A.R.M., Amirul A.A. (2013) Productivity increment of biodegradable and biorenewable copolymer containing 3-hydroxyvalerate monomer initiated by alcohols as precursor substrates. J. Chem. Technol. Biotechnol. 88: 1364-1370.
Shantini K., Yahya A.R.M., Amirul A.A. (2012) Empirical modeling development for integrated process optimization of poly(3-hydrxybutyrate-co-3-hydroxyvalerate) production. J. Appl. Polym. Sci. 125: 2155-2162.

Silva M.G.D., Vargas H., Poley L.H., Rodriguez R.S., Baptista G.B. (2005) Structural impact of hydroxyvalerate in polyhydroxyalkanoates (PHA scl) dense film monitored by XPS and photothermal methods. J. Brazil Chem. Soc. 14: 790-795.

Sudesh K., Bhubalan K., Chuah J.A., Kek Y.K., Kamilah H., Sridewi N., Lee Y.F. (2011) Synthesis of polyhydroxyalkanoate from palm oil and some new applications. Appl. Microbiol. Biotechnol. 89: 1373-1386.

Wang Y.J., Hua F.L., Tsang Y.F., Chan S.Y., Sin S.N., Chua H., Yu P.H.F., Ren N.Q. (2007) Synthesis of PHAs from waster under various C:N ratios. Bioresour. Technol. 98: 1690-1693.

Yatim A.F.M., Syafiq I.M., Huong K.H., Amirul A.A.A., Effendy A.W.M., Bhubalan K. (2017) Bioconversion of novel and renewable agro-industry by-products into a biodegradable poly (3-hydroxybutyrate) by marine Bacillus megaterium UMTKB-1 strain. BioTechnologia 98: 141-151.

Zafar M., Kumar S., Dhiman A.K. (2012) Optimization of polyhydroxybutyrate $(\mathrm{PHB})$ production by Azohydromonas lata MTCC 2311 by using genetic algorithm based on artificial neural network and response surface methodology. Biocatal. Agric. Biotechnol. 1: 70-79.

agar F., Kr an A. (2009) Sequence distribution dependence on molar mass in microbial poly(3-hydroxybutyrate-co-3hydroxyvalerate) copolyesters. Acta Chim. Slov. 52: 386-391.

Zakaria M.R., Ariffin H., Aziz S.A., Hassan M.A., Shirai Y. (2013) Improved properties of poly(3-hydroxybutyrate-co-3hydroxyvalerate) produced by Comamonas sp. EB172 utilizing volatile fatty acids by regulating the nitrogen source. Biomed. Res. Int. 2013: 1-7.

Zakaria M.R., Ariffin H., Johar N.A.M., Aziz S.A., Nishida H., Shirai Y., Hassan M.A. (2010) Biosynthesis and characterization of poly(3-hydroxybutyrate-co-3-hydroxyvalerate) copolymer from wild-type Comamonas sp. EB172. Polym. Degrad. Stab. 95: 1382-1386.

Zhou Y., Han L.R., He H.W., Sang B., Yu D.L., Feng J.T., Zhang X. (2018) Effects of agitation, aeration and temperature on production of a novel glycoprotein GP-1 by Streptomyces kanasenisi ZXO1 and scale-up based on volumetric oxygen transfer coefficient. Molecules 23: 125. 